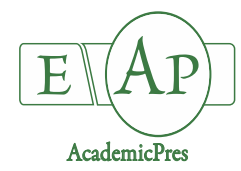

Tounekti T et al. (2020)

Notulae Botanicae Horti Agrobotanici Cluj-Napoca 48(2):938-953

DOI: $10.15835 /$ nbha 48211841

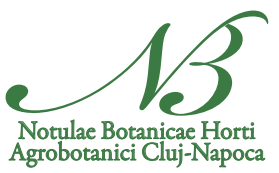

\title{
Priming improves germination and seed reserve utilization, growth, antioxidant responses and membrane stability at early seedling stage of Saudi sorghum varieties under drought stress
}

\author{
Taieb TOUNEKTI ${ }^{1 *}$, Mosbah MAHDHI ${ }^{1}$, Zarraq AL-FAIFI ${ }^{1,2}$, \\ Habib KHEMIRA ${ }^{1}$
${ }^{1}$ Jazan University, Centre for Environmental Research and Studies, Jazan, Saudi Arabia; tounekti_taiebb@yahoo.com (*corresponding author);mosbahtn@yahoo.fr; habibkhemira@yahoo.com
${ }_{2}^{2}$ Jazan University, Department of Biology, Faculty of Science, Jazan, Saudi Arabia; zalfifi@jazanu.edu.sa

\begin{abstract}
Seeds of three sorghum (Sorghum bicolor (L.) Moench.) varieties from southwest Saudi Arabia were used to investigate the potential of osmopriming with polyethylene glycol (PEG 8000) to improve germination performance, seed reserve utilization and early seedling growth and drought stress tolerance. The primed (PS) and unprimed (UPS) seeds of the three sorghum varieties were germinated for 8 days under increasing PEGinduced osmotic stress. The treatments were arranged in a completely randomized design, in a factorial arrangement, with three sorghum cultivars ('Zaydia', 'Shahbi' and 'Ahmar') and four osmotic potentials (0.0; $0.4 ;-0.8$ and $-1.2 \mathrm{MPa}$ ) with four replicates of 50 seeds each. The results showed that drought stress affected seed germination and seedling emergence and establishment, but increased the activity of the antioxidant enzyme catalase (CAT). The strongest inhibition of germination and growth occurred at the highest PEG concentration and a significant difference was noticeable between the studied varieties. We confirmed also that seed osmopriming improved seed germination performance, seedling growth and enhanced the CAT activities while reduced malonyldialdehyde (MDA) accumulation and electrolyte leakage (EL) in the drought-stressed seedlings. Seed priming have enhanced also the $\alpha$-amylase and total proteases activities in all varieties. The largest increase of these hydrolysing enzymes was shown in 'Ahmar'. Furthermore, the PEG priming lead to improvement of the weight of utilized (mobilized) seed reserve (WUSR), seed reserve depletion percentage (SRDP), and total seedling dry weight (SLDW) of sorghum seedlings under water stress conditions. Still the highest values or all three parameters were found in the 'Ahmar' variety. Under increasing drought stress conditions, 'Ahmar' showed the highest yield stability index (YSI) and the least EL and MDA contents in comparison to the other two varieties during the seedling establishment stage. Therefore, the former variety can tolerate better a rigorous water stress condition. 'Zaydia' appears to be the most vulnerable to drought stress. Thus, the use of species or varieties with eminent seed metabolic quality is an advantageous trait in drought-prone regions.
\end{abstract}

Keywords: drought tolerance; early seedling growth; germination performance; PEG priming; seed reserve mobilization; Sorghum bicolor; varieties 


\section{Introduction}

Drought stress is a serious agronomic problem in arid and semi-arid areas of the world and is one of the key factors reducing plant growth and productivity. Although sorghum [Sorghum bicolor (L.) Moench.] is commonly considered tolerant to abiotic stresses mainly drought and salinity as compared to other cereal crops but still it is sensitive at diverse growth stages to many stresses (Ejeta and Knoll, 2007; Teshome et al., 2018). The recognition of the genetic and the physiological mechanisms underlying drought tolerance in sorghum is vital for physiologists and plant breeders in order to boost productivity (Ejeta and Knoll, 2007; Tsago et al., 2014). Still the traits related to drought tolerance of the sorghum varieties in Saudi Arabia are not yet identified while there is a variation within a lot of them. For these varieties, water shortage take place habitually during the early growing season in spring (Zhang et al., 2015). In addition, in these semi-arid areas, the rainfall fluctuation as a result of climate change frequently causes variations in soil water content which may harmfully affect the seedling establishment and plant growth and yield (Hamidi and Safarnejad, 2010). If prolonged over to a certain extent drought stress will inevitably generate reactive oxygen species (ROS) (Tounekti et al., 2012, Tounekti et al., 2018). These ROS react with cellular constituents, causing protein degradation, lipid peroxidation and DNA damage (Tounekti et al., 2018). Efficient scavenging of ROS produced under stressful conditions requires the action of several non-enzymatic and enzymatic antioxidants in cellular organelles (Tounekti et al., 2012; Hasanuzzaman et al., 2013; Zrig et al., 2019). Catalase (CAT), superoxide dismutase (SOD), ascorbate peroxidase (APX) and several other enzymes are well known enzymatic antioxidant components (Zrig et al., 2019). Plants can also deal with the soil moisture stress by the osmotic adjustment process (Tounekti et al., 2018).

In general, seed germination and seedling emergence and establishment are less tolerant to abiotic stress as compared to adult plants; thus, water deficit stress during these early stages may result in high mortality rates and low crop performance (Zhang et al., 2015). Seed priming is one of the efficient and effective techniques that can be used to reduce the undesirable effects of stress and to improve crop performance (GhassemiGolezani et al., 2008; Patade et al., 2011; Jisha et al., 2013; Zhang et al., 2015). Generally primed seeds demonstrate a faster and more harmonized germination and the emerged seedlings are more vigorous and tolerant to abiotic stresses than seedlings emerged from unprimed seeds (Bradford, 1986; Hur, 1991). Priming is a pre-sowing treatment that consists of soaking the seeds in an osmoticum of low water potential to induce a physiological state that enables seed to germinate more efficiently and later allow plant reacts more rapidly and more efficiently to a stress (Jisha et al., 2013; Rahimi 2013). Research demonstrated that seeds osmoprimed with polyethylene glycol (PEG) is effective to improve germination, emergence, and seedling establishment of several plants, especially under stress conditions (Zhang et al., 2015; Shihab and Hamza, 2019). For example, Shihab and Hamza (2019) reported that germination and seedling establishment of sorghum under drought, cold stress, and high salinity were improved following seed osmopriming with PEG. Similar improvements were also noted for rice (Oryza sativa L.) under drought after seed osmopriming with PEG (Li et al., 2011). Still, the physiological processes behind the efficient germination and the vigorous seedling formation after seed priming are ambiguous. Therefore, comprehensive research is reasonable to reveal such physiological mechanisms involved in drought stress tolerance of there sorghum varieties originated from Saudi Arabia after osmopriming with PEG. These varieties represent a highly valuable genetic pool because of their presumed water stress tolerance since they grow and provide good yields in an area often inflicted by severe droughts. The present study considered for the first time to our knowledge the ability of PEG osmopriming to induce seed germination performance, seed reserve mobilisation and early seedling growth and antioxidant defence of three sorghum varieties largely cultivated in the south-western Saudi Arabia. Still, the activities of some enzymes associated to seed reserve mobilization ( $\alpha$-amylase and total proteases) were also explored. 


\section{Materials and Methods}

\section{Plant material}

Seeds of three sorghum [Sorghum bicolor (L.) Moench.] varieties were obtained from Seed collection of the Center for Environmental Research and Studies (CERS), Jazan University. These varieties are originated from the Southwest of Saudi Arabia where they have been grown for many centuries and are still widely used by farmers in their traditional agro-ecosystems. They are opening pollinated from which rural farmers retain seed for planting in the next season. These varieties varied in colour from white, red to brown. These varieties are locally known as 'Zaydia' (white variety), 'Shahbi' (brown variety) and 'Ahmar' (red variety).

\section{Seed priming and germination tests}

The sorghum seeds from three sorghum varieties ('Zaydia', 'Shahbi' and 'Ahmar') were surface-sterilized by using $6 \%(\mathrm{v} / \mathrm{v})$ sodium hypochlorite for $5 \mathrm{~min}$ at room temperature and then rinsed with sterile distilled $\mathrm{H}_{2} \mathrm{O}$. Sorghum seeds were primed in 20\% (w/v) polyethylene glycol 8000 (PEG 8000) solution for $48 \mathrm{~h}$ at 18 ${ }^{\circ} \mathrm{C}$ in dark aseptic conditions. Seeds were then washed with distilled $\mathrm{H}_{2} \mathrm{O}$ and dried at room temperature to their original weight. Unprimed seeds were used as a control. Afterward, primed (PS) and unprimed (UPS) seeds of the three sorghum varieties were germinated in growth chamber at $25^{\circ} \mathrm{C}$ in Petri dishes containing filter paper properly moistened with increasing concentration of PEG 6000 which correspond to four osmotic potential $\left(\Psi_{s}\right)$ levels: 0 (control); - 0.4; - 0.8 and - 1.2 MPa. The equation of Michel and Kaufmann (1973) was used to determine the appropriate PEG-6000 concentrations for each osmotic potential value. A completely randomized design, in a factorial plan was used (three varieties $\mathrm{x}$ four osmotic potentials $\mathrm{x}$ four replicates). Germinated seeds were recorded every $12 \mathrm{~h}$ for 8 days.

\section{Measurements of seed germination and seedling growth}

The germination capacity (GC), germination rate index (GRI), mean germination time (MGT), and early growth of sorghum seedlings were calculated as follow:

Germination capacity (\%): GC (\%) $=\mathrm{n}_{\mathrm{g}} / \mathrm{n}_{0} \times 100$, where $\mathrm{n}_{\mathrm{g}}$ is the number of germinated seeds, and $\mathrm{n}_{0}$ is the total number of seeds ( 50 seeds).

Germination rate index $\left(\right.$ seed day $\left.{ }^{-1}\right):$ GRI $=\Sigma\left(n_{i} / t_{i}\right)$, where $n_{i}$ is the number of germinated seeds on a given day, and $t_{i}$ is the time in days from the sowing day (Maguire, 1962).

Time to $50 \%$ germination $(T 50)=\frac{\left(t i+\left(\left(\frac{N}{2}\right)-n i\right)\right)(t i-t j)}{n i-n j}$, where $N$ is the final number of germination and $n i, n j$ are cumulative number of seeds germinated at times $t i$ and $t j$ when $n i<N / 2<n j$.

Mean germination time (day): MGT $=\left(\sum n_{i} t_{i}\right) / \Sigma$ ni, where $n_{i}$ is the number of germinated seeds on a given day, and $t_{i}$ is the time in days from the sowing day (Labouriau, 1983).

Seedling vigour index: $S V I=S L \times \sum\left(n_{i} / t_{i}\right)$, where $S L$ is the shoot length, $n_{i}$ is the number of germinated seeds on a given day, and $t_{i}$ is the time in days from the sowing day (Zhang et al., 2007).

The shoot and root length $(\mathrm{mm})$ were measured at the $8^{\text {th }}$ day on 20 randomly selected seedlings. The dry matter of shoots and roots were recorded after oven drying at $65^{\circ} \mathrm{C}$ for $72 \mathrm{~h}$. The data of total dry matter production were recorded for each crop at each PEG treatment and used to calculate the drought tolerance indices as follow:

Yield stability index: YSI $=\mathrm{Y}_{\text {stress }} / \mathrm{Y}_{\text {control, }}$, where $\mathrm{Y}_{\text {stress }}$ and $\mathrm{Y}_{\text {control }}$ are the total dry matter yield $(\mathrm{mg}$ per seedling) under drought stress and non-stress conditions (control), respectively (Bouslama and Schapaugh, 1984). The shoot and root lengths were measured at the $8^{\text {th }}$ day of sowing. The root: shoot ratio (RSR) was also calculated. 


\section{Determination of seed reserve utilization}

For the evaluation of seed reserve utilization, four replicates of sorghum seeds ( 25 seeds per replicate) were weighed (W1), dried at $104{ }^{\circ} \mathrm{C}$ for $24 \mathrm{~h}$ and then reweighed (W2). Seed water content (WC) was calculated as [(W1-W2)/W2].

According to the corresponding WC, the initial seed dry weight (ISDW; mg per seed) of each sorghum was calculated as [W $1 \times(1-\mathrm{WC}) / 25]$.

Primed and unprimed seeds of the three sorghum varieties were then germinated in Petri dishes with increasing PEG treatments. After eight days of germination, the shoots and roots of seedlings were separated from the seeds by hand. The seedlings dry weight (SLDW) and the remnant seed dry weight (RSDW; mg per seed) were obtained after oven drying at $104^{\circ} \mathrm{C}$ for $24 \mathrm{~h}$ (Soltani et al., 2006). The weight of the utilised (mobilized) seed reserve (WUSR) was calculated as (ISDW - RSDW).

The seed reserve utilization efficiency (SRUE) was calculated as (SLDW / WUSR) (Soltani et al., 2006).

The seed reserve depletion percentage (SRDP) was calculated as WUSR/ ISDW.

\section{Determination of protease activity}

The protease (EC 3.4.2.21) was assayed according to the method described by Li et al. (2011) with modifications. $1 \mathrm{~g}$ of germinated seeds homogenized in a mortar in $10 \mathrm{~mL}$ of extraction medium ( $50 \mathrm{mM}$ TrisHCL pH 7.5, $5 \mathrm{mM} \beta$-mercaptoethanol). The homogenate was centrifuged at $20,000 \mathrm{xg}$ for $30 \mathrm{~min}$ at $4{ }^{\circ} \mathrm{C}$, and the supernatant was used for protease activity measurements. $1 \mathrm{ml}$ of enzyme extract and $1 \mathrm{ml}$ of substrate solution $(0.6 \%$ casein in $0.1 \mathrm{M}$ Tris HCL buffer, $\mathrm{pH} 8.0)$ were incubated for $10 \mathrm{~min}$ at $40{ }^{\circ} \mathrm{C}$. The reaction was stopped by incubating at $90^{\circ} \mathrm{C}$ for $5 \mathrm{~min}$ and by adding $2 \mathrm{~mL}$ of $10 \%(\mathrm{v} / \mathrm{v})$ trichloracetic acid (TCA). Each test tube was allowed to stand for $15 \mathrm{~min}$ at room temperature. The mixture was centrifuged at $20,000 \mathrm{xg}$ for $10 \mathrm{~min} .500 \mu \mathrm{L}$ of the supernatant was added to $1 \mathrm{~mL}$ of $1 \mathrm{M} \mathrm{NaOH}$, and the absorbance was taken at $280 \mathrm{~nm}$ (UV-2600, Shimadzu, Suzhou, China). A control was used with the addition of TCA prior to sample incubation. A tyrosine standard calibration curve is constructed to determine the amount of tyrosine released after the proteolytic activity. A series of tyrosine standard solutions at different concentrations $(5-50 \mu \mathrm{g} / \mathrm{mL})$ were prepared from the $0.18 \mathrm{mg} / \mathrm{mL}$ L-tyrosine stock solution with deionized water.

a-amylase activity of the germinated seeds

$\alpha$-amylase activity was determined according to the method of Jones and Varner (1967). Frozen germinated seeds (after 4 days) were ground in $5 \mathrm{ml}$ ice-cold buffer $\left(0.05 \mathrm{~mol} \mathrm{~L}^{-1}\right.$ acetate buffer) then centrifuged $(16,000 \mathrm{xg})$ for $15 \mathrm{~min}$ at $4^{\circ} \mathrm{C}$. The supernatant was taken for measurement. The substrate for $\alpha-$ amylase was $1 \%$ solution of soluble starch in $0.1 \mathrm{~mol} \mathrm{~L}^{-1}$ acetate buffer. The reaction was started by the addition of $1.0 \mathrm{ml}$ of starch substrate for one hour. The mixtures were put in a boiling water bath for $5 \mathrm{~min}$ then cooled to room temperature. The reaction was stopped by the addition of $1 \mathrm{ml}$ of iodine reagent. To this reaction mixture, $5.0 \mathrm{ml}$ of distilled water was added, mixed and measured the absorption at $620 \mathrm{~nm}$. The $\alpha$-amylase activity was calculated as the amount of starch hydrolysed per minute per $\mathrm{mg}$ of protein.

\section{Electrolyte leakage (EL) and malonyldialdehyde (MDA) contents in seedlings}

Six seedlings per treatment per variety were considered for both analyses. The EL(\%) was determined as described by Ghoulam et al. (2002). Briefly, fresh seedlings $(50 \mathrm{mg})$ were placed in tubes containing $10 \mathrm{~mL}$ of double-distilled water then incubated at $25^{\circ} \mathrm{C}$ for $24 \mathrm{~h}$ in a rotary shaker and the initial electrical conductivity of the medium $\left(\mathrm{EC}_{1}\right)$ was measured using a conductivity meter. Then, samples were autoclaved at $121^{\circ} \mathrm{C}$ for $20 \mathrm{~min}$ to release all electrolytes and cooled to $25^{\circ} \mathrm{C}$, after which the final electrical conductivity $\left(\mathrm{EC}_{2}\right)$ was measured. The $\mathrm{EL}(\%)$ was calculated as follow: $\mathrm{EL}(\%)=\left(\mathrm{EC}_{1} / \mathrm{EC}_{2}\right) \times 100$. 
The MDA content was determined after 8 days of germination according to Hodges et al. (1999) which takes into account the possible influence of interfering compounds in the thiobarbituric acid (TBA)-reactive substances assay.

\section{Catalase enzyme activity in seedlings}

Six seedlings per treatment per variety were considered for CAT analyses. Fresh seedlings $(100 \mathrm{mg})$ were grinded in liquid $\mathrm{N}_{2}$ then extracted with $1 \mathrm{~mL}$ of cold $\mathrm{K}_{2} \mathrm{HPO}_{4}$ buffer $(50 \mathrm{mM}, \mathrm{pH} 7.5)$ containing $2 \%(\mathrm{w} / \mathrm{v})$ PVP and EDTA $(1 \mathrm{mM})$. After centrifugation for $10 \mathrm{~min}$ at $4{ }^{\circ} \mathrm{C}$ at $22,000 \times \mathrm{g}$, the supernatants were used to measure protein content and CAT by spectrophotometer (Aebi, 1984). One millilitre of reaction mixture containing $50 \mathrm{mM} \mathrm{K}_{2} \mathrm{HPO}_{4}$ buffer ( $\mathrm{pH} 7.0$ ) and $250 \mu \mathrm{l}$ of enzyme extract is initiated by adding $60 \mathrm{mM}$ of $\mathrm{H}_{2} \mathrm{O}_{2}$. The CAT activities were measured at $240 \mathrm{~nm}$ for $3 \mathrm{~min}$ and expressed in enzyme units using an extinction coefficient of $39.3 \mathrm{mM}^{-1} \mathrm{~cm}^{-1}$. One unit of activity is equivalent to $1 \mathrm{mM}$ of $\mathrm{H}_{2} \mathrm{O}_{2}$ degraded per minute and is expressed as unit per gram of protein.

\section{Statistical analysis}

The three-way ANOVA analysis was performed using SAS software (SAS Institute Inc. 2004). Three replicates per variety and per treatment were used. Turkey's test was used for the comparison of means.

\section{Results}

\section{Effect of seed priming and drought stress on germination}

The results of variance analysis (Table 1$)$ showed significant effects $(P<0.05)$ for the PEG priming, varieties and osmotic potential levels, as well as for interactions, for the majority of the studied germination traits. The germination response of seeds from the tested varieties was negatively affected $(P<0.001)$ by the PEG-induced drought stress (Figure 1). For all germination traits, the variety of Ahmar was superior compared to others two varieties. The germination capacity (GC\%) in primed (PS) and unprimed (UPS) seeds was notably reduced by increasing the medium water potential. Still, the values of GC\% of the PS were significantly superior compared to the values of the UPS. At the highest water potential, the PS of 'Ahmar', 'Shahbi' and 'Zaydia' varieties reached a GC\% of 84.12\%, 79.07\% and 74.72\% respectively, while the UPS presented GC\% values of $77.21 \%, 72.56 \%$ and $69.34 \%$ respectively under the similar conditions. For all varieties, the mean germination time (MGT) has been delayed significantly $(P<0.001)$ by increasing drought stress. MGT did not differ significantly between varieties (Table 1). The PS of 'Ahmar', 'Shahbi' and 'Zaydia' presented MGT values of $2.17 \pm 0.09,2.36 \pm 0.14$ and $2.44 \pm 0.12$ respectively at the highest water potential level in comparison to $1.91 \pm 0.15,1.99 \pm 0.15$ and $2.19 \pm 0.20$ for respectively the UPS (Figure 1). The seed priming considerably accelerated the T50 of the tested sorghum varieties under drought stress $(P<0.01$, Table 1$)$ with different pattern between them. The PS of 'Ahmar', 'Shahbi' and 'Zaydia' varieties accelerated their germination under severe drought stress of $-1.2 \mathrm{MPa}$ to reach $2.98 \pm 0.15,3.08 \pm 0.10$ and $3.26 \pm 0.12$ days respectively. The values of $3.45 \pm 0.17,3.47 \pm 0.12$ and $3.72 \pm 0.13$ days were respectively measured for the UPS of the same cultivars (Figure 1). The germination rate index (GRI) of sorghum seeds varied from 63.84 to 66.74 seed day ${ }^{-1}$ and was considerably reduced with the increase of the drought stress (Figure 1). The seed priming significantly accelerated the GRI under increasing water potential with diverse behaviours between the varieties $(P<0.001)$. 
Table 1. Results of variance analysis of water deficit, PEG priming, sorghum varieties and their interactions for GC, GRI, MGT, T50, SVI, SRD, SRUE, SLDW, WUSR, protease activity, $\alpha$-amylase activity

\begin{tabular}{|c|c|c|c|c|c|c|c|c|c|c|c|c|}
\hline & & \multicolumn{11}{|c|}{ Dependent variables } \\
\hline & $\mathrm{df}$ & GC & GRI & MGT & T50 & SVI & SRD & SRUE & SLDW & WUSR & Protease & $\alpha$-amylase \\
\hline Varieties (V) & 2 & $7.49^{* *}$ & $9.45^{*}$ & $0.8 \operatorname{lns}$ & $1.47 \mathrm{~ns}$ & $12.92^{* *}$ & $18.37^{*}$ & $11.91^{*}$ & $5.77^{*}$ & $3.35 \mathrm{~ns}$ & $4.84^{* *}$ & $5.80^{* *}$ \\
\hline Water deficit & 3 & $43.41^{*}$ & $260.69^{*}$ & $8.14^{* *}$ & $14.45^{* *}$ & $556.63^{*}$ & $41.64^{*}$ & $88.67^{*}$ & $135.2^{*}$ & $63.74^{*}$ & $48.01^{* *}$ & $89.57^{* *}$ \\
\hline Priming $(\mathrm{P})$ & 1 & $9.26^{* *}$ & $2.62 \mathrm{~ns}$ & $49.71^{*}$ & $52.98^{* *}$ & $2.29 \mathrm{~ns}$ & $2.84 \mathrm{~ns}$ & $1.29 \mathrm{~ns}$ & $9.31^{*}$ & $10.22^{*}$ & $17.18^{* *}$ & $12.84^{* *}$ \\
\hline Vx WD & 6 & $0.32 \mathrm{~ns}$ & $8.53^{*}$ & $0.33 \mathrm{~ns}$ & 0.064 & $4.62^{*}$ & $1.55 \mathrm{~ns}$ & $15.94^{*}$ & $0.64 \mathrm{~ns}$ & $0.92 \mathrm{~ns}$ & $5.17^{*}$ & $8.34^{*}$ \\
\hline $\mathrm{V} \times \mathrm{P}$ & 2 & $0.01 \mathrm{~ns}$ & $0.01 \mathrm{~ns}$ & $0.01 \mathrm{~ns}$ & 0.028 & 0.001 & $0.04 \mathrm{~ns}$ & $0.01 \mathrm{~ns}$ & $0.01 \mathrm{~ns}$ & $0.01 \mathrm{~ns}$ & $0.001 n$ & $0.30 \mathrm{~ns}$ \\
\hline WD $\times P$ & 3 & $0.04 \mathrm{~ns}$ & $0.01 \mathrm{~ns}$ & $0.11 \mathrm{~ns}$ & $0.21 \mathrm{~ns}$ & $0.34 \mathrm{~ns}$ & $0.26 \mathrm{~ns}$ & $0.035 n$ & $0.55 \mathrm{~ns}$ & $0.40 \mathrm{~ns}$ & $0.07 \mathrm{~ns}$ & $0.03 \mathrm{~ns}$ \\
\hline $\mathrm{V} \times \mathrm{WD} \times \mathrm{P}$ & 6 & $0.03 \mathrm{~ns}$ & $0.01 \mathrm{~ns}$ & $0.12 \mathrm{~ns}$ & $0.18 \mathrm{~ns}$ & $0.21 \mathrm{~ns}$ & $0.13 \mathrm{~ns}$ & $0.02 \mathrm{~ns}$ & $0.43 \mathrm{~ns}$ & $0.31 \mathrm{~ns}$ & $0.02 \mathrm{~ns}$ & $0.01 \mathrm{~ns}$ \\
\hline
\end{tabular}

GC: germination capacity. GRI: germination rate index. MGT: mean germination time. T50: Time to $50 \%$ germination SVI: seedling vigor index. SRD Seed reserve depletion percentage. SRUE: Seedling reserve utilization efficiency. SLDW: Seedling total dry weight. WUSR: Weight of utilized seed reserve.

Numbers represent F-values at 0.05 probability level, ${ }^{*},{ }^{* *}$, Significant at the 0.05 , and 0.01 , probability levels, respectively; ns: non-significant at 0.05 probability level
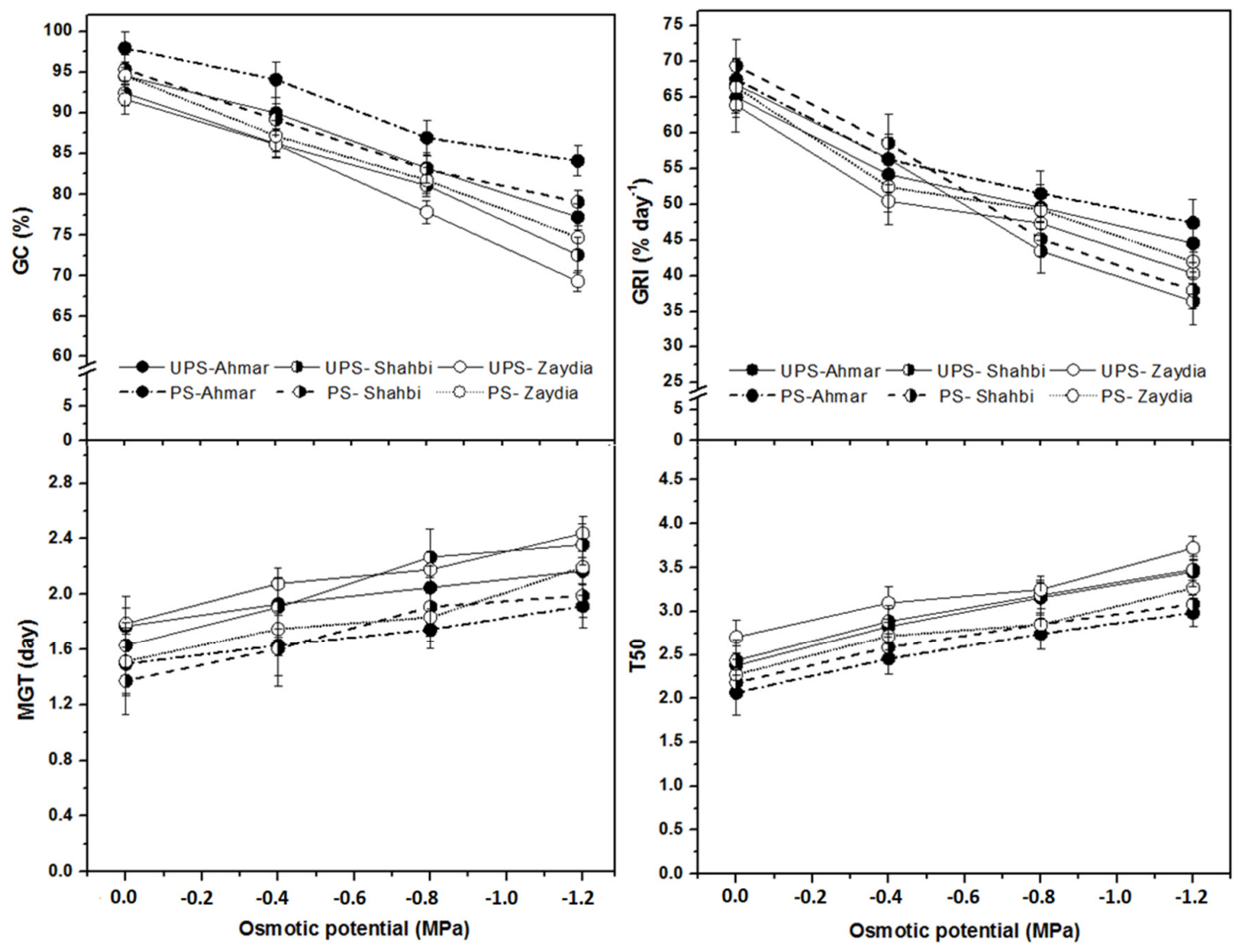

Figure 1. Effect of PEG priming and drought stress induced by PEG6000 on germination capacity (GC), germination rate index (GRI), mean germination time (MGT) and Time to $50 \%$ germination (T50) of sorghum varieties. Data represent the mean $( \pm \mathrm{SE})$ of at least four replicates

\section{Seed reserve mobilisation}

Results of variance analyses showed significant effects for the PEG priming, varieties and water deficit levels, as well as for interactions, for most of the measured traits concerning the seed reserve mobilisation and seedling growth (Table 1). Still, osmopriming did not significantly affect the SRUE. It varied mostly between varieties, with the highest values was recorded for 'Zaydia' under control conditions. Under increasing drought stress, PS of all varieties had a greater SRDP, WUSR and SLDW than UPS (Figures 2 and 3). For all varieties, 
the highest values of these parameters were recorded for the PS and under the lowest water potential (control treatment). Significant $(P<0.001)$ variability between the varieties was recorded in this regards (Table 1$)$. The highest values of seed mobilisation parameters were found in 'Ahmar' compared to the other two varieties. When primed the seeds of 'Ahmar' showed the lowest decrease of SLDW (66.4\%), SRUE (20.8\%), WUSR $(60.3 \%)$ and SRDP $(59.8 \%)$ under the highest drought stress $(-1.2 \mathrm{MPa})$. For the same conditions, 'Zaydia' showed the largest decrease of these parameters with $77.6 \%, 70.4 \%, 70.9$ and $72.7 \%$ respectively (Figure 3).
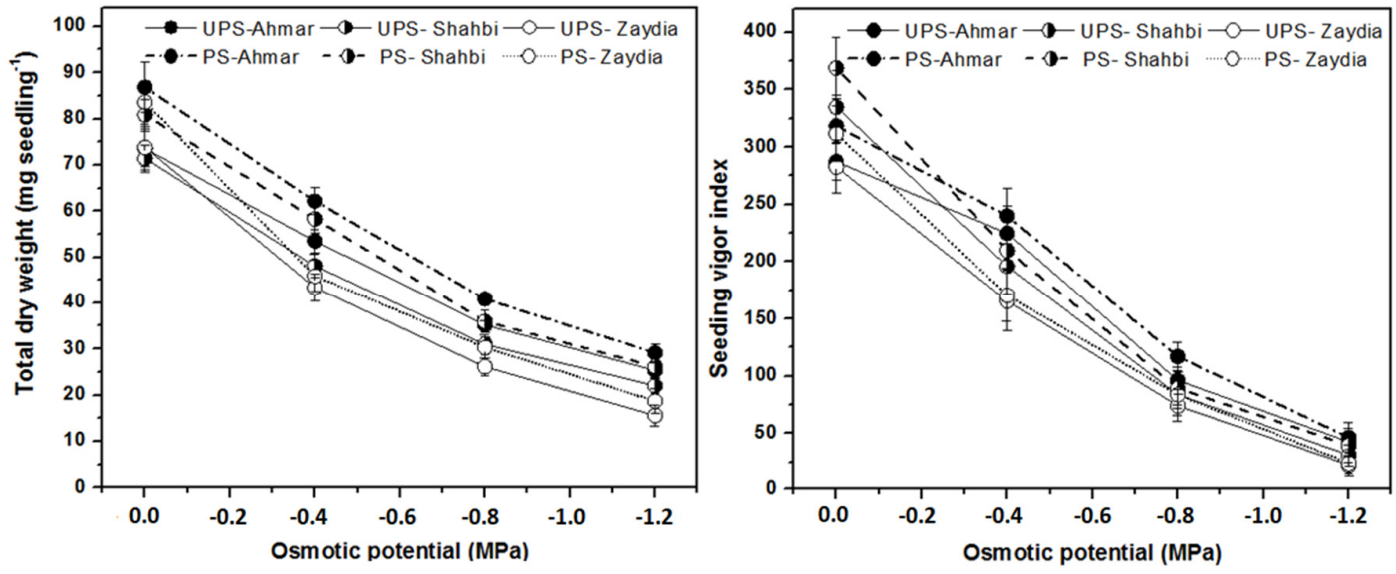

Figure 2. Effect of PEG priming and drought stress induced by PEG6000 on seedling vigor index (SVI) and seedling total dry weight (SLDW) of sorghum varieties. Data represent the mean $( \pm S E)$ of at least four replicates

\section{Changes in total proteases and $\alpha$-amylase activities}

The results of variance analysis (Table 1) showed significant effects for the PEG priming, varieties and osmotic potential levels, as well as for interactions, for total proteases and $\alpha$-amylase activities. The total proteases and $\alpha$-amylases in the seeds exhibited a significant decline in activity with increasing drought stress (Figure 4). For both PS and UPS, the lowest decreases of both hydrolysing enzymes were shown by Ahmar under the highest water potential (-1.2 MPa). When primed the seeds of 'Zaydia' showed the largest decrease of total proteases (56.6\%) and $\alpha$-amylases $(67.8 \%)$ under the highest drought stress $(-1.2 \mathrm{MPa})$. Seed priming was found to increase the $\alpha$-amylase and total proteases activities to many folds in all sorghum varieties. Still the largest increase of these hydrolysing enzymes was shown in Ahmar followed by 'Shahbi' and finally the 'Zaydia'.

\section{Effect of seed priming and drought stress on early seedling growth}

The results of variance analysis (Table 2) showed significant effects for the PEG priming, varieties and osmotic potential levels, as well as for interactions, for shoot and root lengths as well as for the root to shoot ratio (RSR). Our results showed that the shoot and root lengths of sorghum seedlings were significantly $(P<$ 0.001 ) reduced with the increase of osmotic potential levels in all sorghum varieties (Table 2). For all traits considered, the variety of 'Ahmar' was superior compared to others two varieties. For all varieties, the maximum values for shoot length and root length was observed in control $(0 \mathrm{MPa})$ and the minimum values were observed under severe drought stress $(-1.2 \mathrm{MPa})$. The reductions of the shoot lengths were greater than the reductions observed for the root lengths under drought stress conditions, which obviously increased the RSR in the all varieties. 'Ahmar' showed the highest RSR compared the other two varieties at all levels of osmotic potential. Seeds priming improved significantly the shoot and root lengths, particularly in 'Ahmar' that reached $0.86 \pm 0.07$ and $0.90 \pm 0.10 \mathrm{~cm}$ respectively for shoot and root lengths under water potential of $-1.2 \mathrm{MPa}$ (Table 2). 
The YSI of sorghum seedlings ranged from 0.49 to 0.69 , depending on the variety, and was considerably decreased with the increase of drought stress in the medium (Figure 5). 'Ahmar' variety had higher YSI compared to the other two varieties when subjected to an increasing osmotic potential. For -1.2 MPa water potential the decrease of the YSI was lower for 'Ahmar' (50.8\%) when compared to 'Zaydia' (62.3\%).

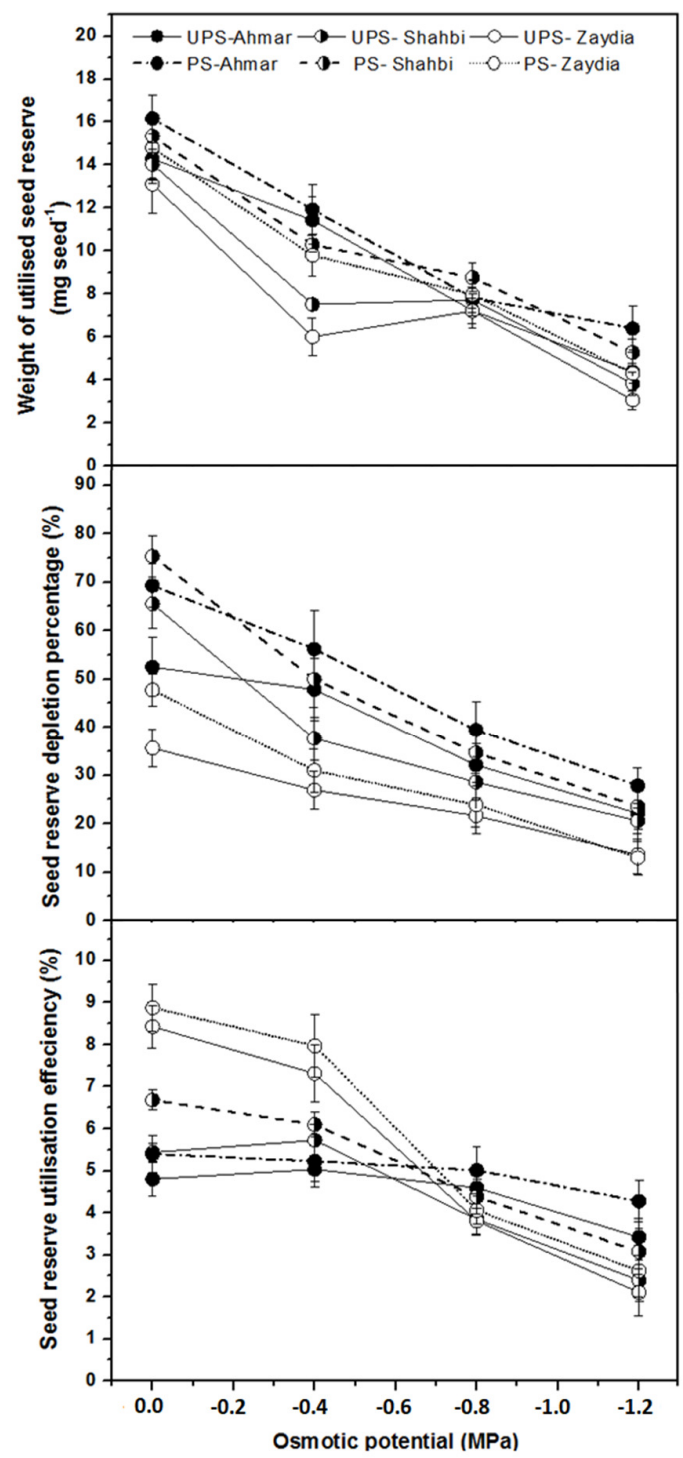

Figure 3. Effects of PEG priming on seed reserve depletion percentage (SRD), seed reserve utilization efficiency (SRUE), and weight of utilized seed reserve (WUSR) of three varieties of sorghum under different drought stress conditions $(0,-0.4,-0.8$ and $-1.2 \mathrm{MPa})$. Data represent the mean $( \pm S E)$ of at least four replicates 

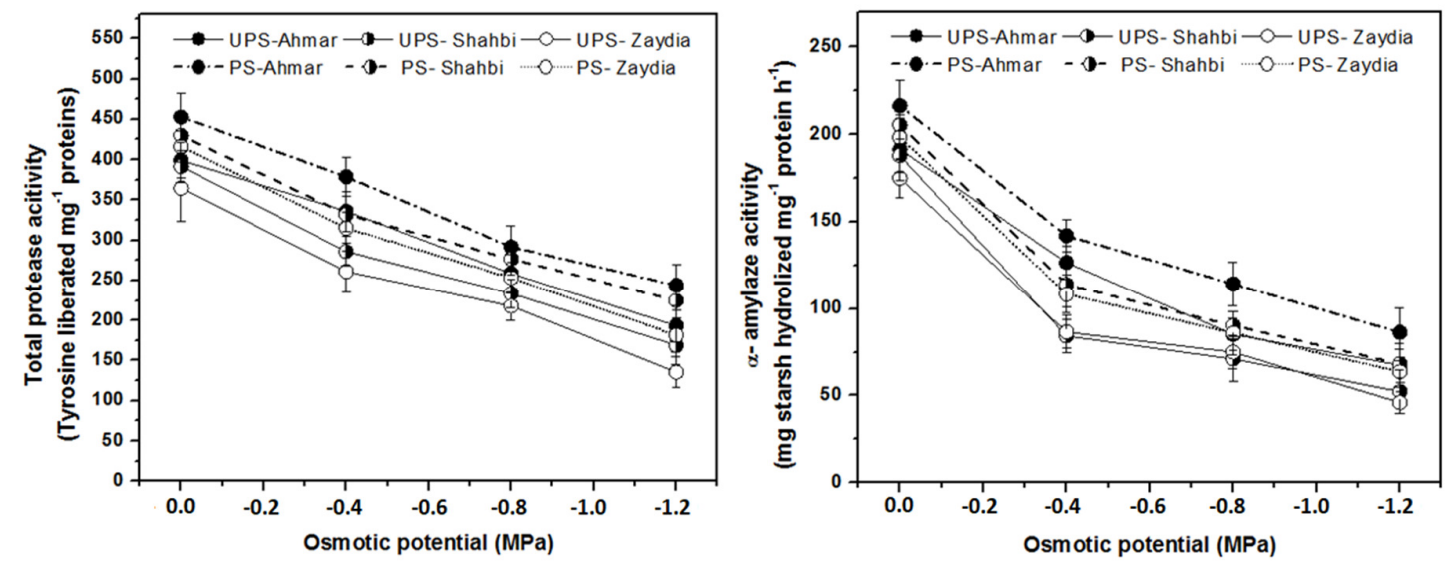

Figure 4. Effects of PEG priming on the total protease activity and $\alpha$-amylase activity in the seeds of three varieties of sorghum under different drought stress conditions (0, -0.4, -0.8 and -1.2 MPa). Data represent the mean $( \pm S E)$ of at least four replicates
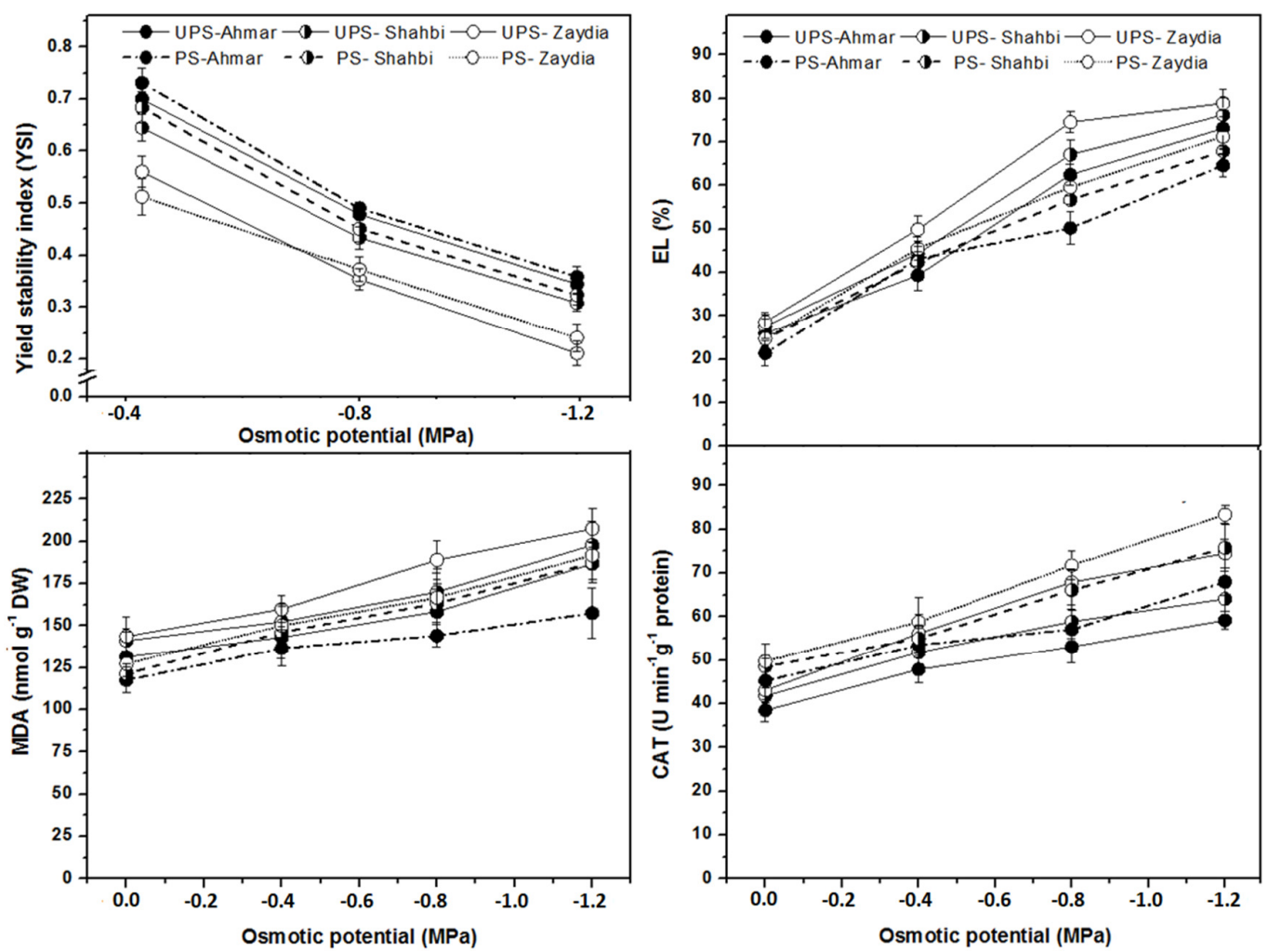

Figure 5. Effects of PEG priming on Yield stability index (YSI), electrolytes leakage (EL), catalase (CAT) and malondialdehyde (MDA) contents in leaves of three varieties of sorghum under different drought stress conditions $(0,-0.4,-0.8$ and $-1.2 \mathrm{MPa})$. Data represent the mean $( \pm \mathrm{SE})$ of at least four replicates. 
Table 2. Effects of PEG priming (PS) on some growth parameters of sorghum varieties as compared to the unprimed controls under (UPS) 0, - 0.4, - 0.8 and - 1.2 MPa of PEG

\begin{tabular}{|c|c|c|c|c|c|c|c|}
\hline \multirow{4}{*}{ Sorghum varieties } & \multirow{2}{*}{$\begin{array}{c}\text { Osmotic } \\
\text { potential } \\
(\mathrm{MPa})\end{array}$} & \multicolumn{2}{|c|}{ Shoot length $(\mathrm{cm})$} & \multicolumn{2}{c|}{ Root length $(\mathrm{cm})$} & \multicolumn{2}{c|}{ Root to shoot ratio } \\
\cline { 3 - 8 } & UPS & PS & UPS & PS & UPS & PS \\
\hline \multirow{4}{*}{ 'Ahmar' } & Control & $9.90 \pm 0.73$ & $10.50 \pm 0.75$ & $3.53 \pm 0.58$ & $3.75 \pm 0.62$ & $0.36 \pm 0.06$ & $0.36 \pm 0.06$ \\
\cline { 2 - 8 } & -0.4 & $3.30 \pm 0.17$ & $3.68 \pm 0.13$ & $3.00 \pm 0.25$ & $3.19 \pm 0.26$ & $0.91 \pm 0.07$ & $0.87 \pm 0.08$ \\
\cline { 2 - 8 } & -0.8 & $1.14 \pm 0.10$ & $1.29 \pm 0.10$ & $1.27 \pm 0.12$ & $1.34 \pm 0.15$ & $1.11 \pm 0.14$ & $1.04 \pm 0.15$ \\
\cline { 2 - 8 } & -1.2 & $0.76 \pm 0.04$ & $0.86 \pm 0.07$ & $0.85 \pm 0.03$ & $0.90 \pm 0.10$ & $1.11 \pm 0.09$ & $1.05 \pm 0.09$ \\
\hline \multirow{3}{*}{ 'Zaydia' } & Control & $8.94 \pm 0.47$ & $9.47 \pm 0.50$ & $3.52 \pm 0.29$ & $3.82 \pm 0.30$ & $0.39 \pm 0.05$ & $0.40 \pm 0.05$ \\
\cline { 2 - 8 } & -0.4 & $2.70 \pm 0.11$ & $3.00 \pm 0.12$ & $2.98 \pm 0.37$ & $3.21 \pm 0.34$ & $1.10 \pm 0.13$ & $1.07 \pm 0.14$ \\
\cline { 2 - 8 } & -0.8 & $1.01 \pm 0.08$ & $1.38 \pm 0.09$ & $0.95 \pm 0.05$ & $1.20 \pm 0.05$ & $0.94 \pm 0.06$ & $0.87 \pm 0.06$ \\
\cline { 2 - 8 } & -1.2 & $0.68 \pm 0.06$ & $0.72 \pm 0.05$ & $0.63 \pm 0.03$ & $0.67 \pm 0.04$ & $0.94 \pm 0.04$ & $0.93 \pm 0.05$ \\
\hline \multirow{3}{*}{ 'Shahbi' } & Control & $7.88 \pm 0.38$ & $8.48 \pm 0.40$ & $4.73 \pm 0.52$ & $5.33 \pm 0.55$ & $0.60 \pm 0.07$ & $0.63 \pm 0.07$ \\
\cline { 2 - 8 } & -0.4 & $2.87 \pm 0.17$ & $2.91 \pm 0.18$ & $3.21 \pm 0.11$ & $3.54 \pm 0.11$ & $1.12 \pm 0.08$ & $1.22 \pm 0.08$ \\
\cline { 2 - 8 } & -0.8 & $0.99 \pm 0.08$ & $1.29 \pm 0.09$ & $0.95 \pm 0.05$ & $1.14 \pm 0.05$ & $0.96 \pm 0.06$ & $0.89 \pm 0.06$ \\
\cline { 2 - 8 } & -1.2 & $0.63 \pm 0.06$ & $0.72 \pm 0.05$ & $0.63 \pm 0.03$ & $0.76 \pm 0.04$ & $1.01 \pm 0.04$ & $1.05 \pm 0.08$ \\
\hline & & $\mathrm{dF}$ & $\mathrm{F}$ & $\mathrm{dF}$ & $\mathrm{F}$ & $\mathrm{dF}$ & $\mathrm{F}$ \\
\hline Varieties & & 2 & $16.33^{* *}$ & 2 & $10.63^{* *}$ & 2 & $16.72^{* *}$ \\
\hline Water deficit & & 3 & $1453.21^{* *}$ & 3 & $451.5^{* *}$ & 3 & $321.72^{* *}$ \\
\hline Priming & & 1 & $1.73 \mathrm{~ns}$ & 1 & $1.61 \mathrm{~ns}$ & 1 & $0.089 \mathrm{~ns}$ \\
\hline Interactions & & 6 & $0.22 \mathrm{~ns}$ & 6 & $0.14 \mathrm{~ns}$ & 6 & $0.15 \mathrm{~ns}$ \\
\hline
\end{tabular}

Means followed by standard errors and different letters are significantly different at $P<0.05 .{ }^{*}$, **, Significant at the

0.05 , and 0.01 , probability levels, respectively; ns: non-significant at 0.05 probability level

\section{Changes in membrane permeability and MDA contents in sorghum seedlings}

The data showed that the independent variables including PEG priming, varieties and osmotic potential levels, and their interactions had significant effect on membrane permeability (EL) and leaf MDA contents (Table 3). Differences between varieties were not significant with regard to the EL. The Figure 5 indicated that EL of the seedlings of all varieties, either originated from UPS or PS, significantly increased with increasing drought stress. Results suggest that seed priming was effective in decreasing membrane permeability by reducing significantly EL of all sorghum seedlings $(P<0.001)$. The variety of 'Ahmar' was superior compared to others two varieties. The 'Zaydia' variety presented the highest EL values (78.8\%) under the highest drought stress ($1.2 \mathrm{MPa})$ in the seedlings originated from UPS, while this harm was significantly less severe when originated from PS (72.1\%).

MDA levels in plant leaves were determined to evaluate lipid peroxidation. Results showed that for all sorghum varieties, the MDA accumulation increase progressively with the increase of the osmotic potential of the medium and remarkably decreased when priming with PEG (Figure 5). Ahmar showed the least MDA increase (least lipid peroxidation) under the water stress, mainly in seedling originated from PS. The seedling of 'Ahmar', 'Shahbi' and 'Zaydia' varieties originated from the primed seeds accumulated $157.46 \pm 14.85$, 193.18 \pm 12.00 , and $196.64 \pm 7.98 \mathrm{nmol} \mathrm{g}^{-1} \mathrm{DW}$ under $-1.2 \mathrm{MPa}$ treatments respectively.

\section{Changes in catalase activities in sorghum seedlings}

The data showed that the independent variables including PEG priming, varieties and osmotic potential levels, and their interactions had significant effect on CAT activities (Table 3). Results showed that for all sorghum varieties CAT activities were significantly improved by the rise of the medium osmotic potential either in seedlings originated from PS or UPS (Figure 5). Seedlings of both PS and UPS of 'Zaydia' variety showed a considerable CAT activity under drought stress level of $-1.2 \mathrm{MPa}$ in comparison to the other two varieties. Under the highest water potential these activities were $69.00 \pm 6.75,71.73 \pm 5.27$ and $82.34 \pm 6.02 \mathrm{IU}$ $\min ^{-1} \mathrm{~g}^{-1} \mathrm{FW}$ for 'Ahmar', 'Shahbi' and 'Zaydia' respectively (Figure 5). 
Table 3. Results of variance analysis of water deficit, PEG priming, sorghum varieties and their interactions for catalase (CAT) activity, malondialdehyde (MDA) contents and electrolytes leakage (EL)

\begin{tabular}{|l|c|c|c|c|}
\hline \multirow{2}{*}{} & \multicolumn{4}{|c|}{ Dependent variables } \\
\cline { 2 - 5 } & $\mathrm{df}$ & CAT & MDA & EL \\
\hline Varieties (V) & 2 & $9.19^{*}$ & $10.50^{*}$ & $2.74 \mathrm{~ns}$ \\
\hline Water deficit (WD) & 3 & $32.99^{*}$ & $42.63^{*}$ & $79.02^{*}$ \\
\hline Priming (P) & 2 & $7.25^{*}$ & $4.81^{*}$ & $16.64^{*}$ \\
\hline Vx WD & 6 & $0.67 \mathrm{~ns}$ & $0.61 \mathrm{~ns}$ & $7.17^{*}$ \\
\hline Vx P & 4 & $5.01^{*}$ & $4.04^{*}$ & $0.007 \mathrm{~ns}$ \\
\hline WD X & 6 & $0.29 \mathrm{~ns}$ & $0.28 \mathrm{~ns}$ & $2.70 \mathrm{~ns}$ \\
\hline Vx WD x & 12 & $0.12 \mathrm{~ns}$ & $0.15 \mathrm{~ns}$ & $1.32 \mathrm{~ns}$ \\
\hline
\end{tabular}

Numbers represent F-values at 0.05 probability level, ${ }^{*}$, ns: Significant and non-significant at 0.05 probability level

\section{Discussion}

Seed priming is one of the methods that can be taken to counteract the harmful effects of abiotic stress (Chen and Arora, 2011; Patade et al., 2011; Jisha et al., 2013). The present study considered for the first time to our knowledge the ability of PEG osmopriming to induce seed germination performance and drought stress tolerance of three sorghum varieties largely cultivated in the south-western Saudi Arabia. Significant effects were shown for PEG priming, sorghum varieties and osmotic potential levels, as well as for their interactions with regards to the most of the traits considered (Table 1). For instance, seed osmopriming have invigorated all sorghum seeds ensuing a larger germination performance and early seedlings growth under increasing water deficit conditions (Figures 1 and 2). We confirmed that priming improved GC\%, GRI, increased the germination speed (decreased MGT and T50) and SVI in all sorghum varieties. Still the positive effect of PEG priming on the sorghum tolerance to water deficit varied significantly among the tested varieties, which may be attributed to the seed reserve composition, the tegument characteristics, and the effectiveness of reserve mobilisation through the several enzymatic reactions (Nascimento and West, 1998, Bove et al., 2001). Ahmar variety showed motivating values in terms of GC, GRI, MGT and T50 even under water stress, mainly when osmoprimed. These results are in agreement with previous findings on some other sorghum varieties (Khan $e t$ al., 2014; Shihab and Hamza, 2019). The positive effect of osmpriming was also reported in other plant species as alfalfa, soybean, cumin, canola, sunflower and rice (Sun et al., 2010; Patade et al., 2011; Rouhi et al., 2011; Sadeghi et al., 2011; Ansari et al., 2012; Amooaghaie, 2013; Rahimi, 2013). Generally, priming was shown to ease the adherence of seed coat which may allow a simple emerging the radical (Nascimento and West, 1998). The effect of increasing osmotic potentials on the germination of sorghum seeds was previously reported and results showed that GRI and GC, as well as the amount of water absorbed by seeds, were noticeably lowered by increasing the osmotic potential of the medium (Oliveira and Gomes-Filho, 2009; Shihab and Hamza, 2019). Besides, with increasing water deficit, the starch and ATP production process were reduced causing a lower GRI and GC and later a lower SVI (Figure 2).

Seeds of diverse species and genotypes have different levels of food storage mainly starch, proteins and lipids (Nascimento and West, 1998; Bove et al., 2001). Such chemical composition of the seeds has great effects on germination performance and seedling growth rate (Finch-Savage and Bassel, 2016). Furthermore, germination may also dependent on the capacity of the seed to utilize (mobilize) these reserves in an appropriate way for better germination characteristics (Sikder et al., 2009). Our results showed that for all sorghum varieties and under increasing drought stress, PS had a greater WUSR, SRDP and SLDW than UPS (Figure 3). Still the highest values of all these seed reserve mobilisation parameters were found in Ahmar variety compared to the other two varieties. The reason for the superiority of Ahmar variety maybe returns to its superiority in the GC\% (Figure 1). This indicates that the seeds produced seedlings have a vigour which should have the ability to make new materials efficiently and quickly to transfer it to the developing embryonic axis, resulting in increased accumulation of dry matter (Shihab and Hamza, 2019). Thus, the use of species or varieties with high seed 
metabolic efficiency is an advantageous trait in drought-prone regions. Besides, the decline in WUSR and SRDP of seeds and seedling growth of all sorghum varieties under increasing water deficit was also previously reported for wheat, tomato, mountain rye and mung bean (De and Kar, 1995; Soltani et al., 2006; Ansari et al., 2012). Generally, the reduction of SRDP and WUSR by drought stress could be due to decrease in gibberellic acid and other hydrolytic enzymes in the germination process (McDonald, 1999). Starch digestion is primarily controlled by $\alpha$-amylase; while the protein degradation is controlled by different proteases (Bishnoi $e t$ al., 1993). Our results showed that the total proteases and $\alpha$-amylases in the seeds exhibited a significant decline in activity with increasing drought stress (Figure 4). Previous reports showed that under water stress $\alpha$-amylase activity were affected in Cicer arietinum cotyledons and in Medicago sativa germinating seeds (Hamidi and Safarnejad, 2010; Khadraji et al., 2017). Furthermore, seed priming was found to enhance the $\alpha$-amylase and total proteases activities in all sorghum varieties. The largest increase of these hydrolysing enzymes was shown in the Ahmar variety. This may suggest that priming have increased the process of proteolysis in the seeds. It was considered that the activities of proteases preserve the respiratory supplies of the growing roots and shoots (Maheshwari and Dubey, 2008). Moreover, the increased level of $\alpha$-amylase activity seems to be liable for parallel increase in the level of non-reducing sugars in PS (Farooq et al., 2006). It appeared that seed priming either induces the de novo synthesis or promotes the activities of existing enzymes (Wang et al., 2009).

The YSI has been considered a good drought tolerance index for crops and varieties (Bouslama and Schapaugh, 1984). The YSI was measured in order to assess the stability of the sorghum seedlings under stressful conditions. Our results showed that the values of YSI varied between varieties, and was considerably decreased with the increase of drought stress in the medium (Figure 5). Ahmar variety had higher YSI compared to the other two varieties when subjected to an increasing osmotic potential. It appeared therefore that the 'Ahmar' variety can tolerate better a rigorous water stress conditions compared to the 'Shahbi' and 'Zaydia'. Generally, drought tolerant plants have the ability to protect their cell membranes by boosting the synthesis of antioxidant enzymes and low antioxidant molecules (Foyer and Noctor, 2005; Tounekti et al., 2012). These antioxidants could neutralize the lethal effect of hydrogen peroxide $\left(\mathrm{H}_{2} \mathrm{O}_{2}\right)$, superoxide $\left(\mathrm{O}_{2}{ }^{-}\right)$and hydroxyl $\left({ }^{\circ} \mathrm{OH}\right)$ radicals in the tissues (Tounekti et al., 2012). Our results showed significant increases of CAT activities in all sorghum seedlings when subjected to an increasing osmotic potential. Still such CAT improvement varied between varieties with the highest increase was shown by 'Zaydia' (the more vulnerable to drought stress). The CAT enzyme plays a key role in the protection and repairing systems under drought stress and particularly when seeds were primed by PEG (Kibinza et al., 2011). In fact CAT enzyme accumulates in the cytosol at the same time with $\mathrm{H}_{2} \mathrm{O}_{2}$ localization during seed priming (Bray, 1995). To explore the effect of PEG osmopriming on membrane stability we measured MDA content and the degree of membrane permeability (EL) in these seedlings subjected to drought stress. MDA is generated when polyunsaturated fatty acids in the cellular membrane undergo oxidative damage (Tounekti et al., 2012). Our results showed that MDA contents were increased in all sorghum varieties when subjected to an increasing osmotic potential, while membrane stability was decreased (increase of EL) suggesting oxidative damage to the plant tissues (Figure 5). Under increasing drought stress conditions, 'Ahmar' variety showed the best membrane health status since it showed the least MDA accumulation and EL amid the three varieties. The low accumulation of MDA in the Ahmar variety (tolerant variety) could be explained by the breakdown of the ROS via increasing CAT activities (Figure 5) which ensure protection from oxidative damage (Sharma et al., 2012). Seed priming was shown to be useful in improving plant drought adaptation by enhancing considerably the cells membrane stability (Figure 5). Rouhi et al., (2012) showed that the germination performance and antioxidant enzyme activities, mainly CAT, in PEG primed seedlings of Berseem clover (Trifolium alexandrinum L.) were significantly improved compared to those in control group. However, the ameliorative effect of seeds osmopriming on stress tolerance of spinach plants may decrease in relatively mature seedlings (Chen and Arora, 2011). It appeared therefore that seed priming largely improved the germination performance and CAT activity in all sorghum seedlings, which have enhanced later the early seedling growth under critical drought stress. Growth and development processes in 
plants are usually very vulnerable to water shortage (Tounekti et al., 2018). Our results confirmed that increasing the water deficit in the medium affects physiological function leading to growth retardation in plants (Table 2). In water stress conditions, seedling growth is affected due to the decline of water uptake by the plants and lower cell turgor pressure (Taiz et al., 2017). Different sorghum varieties responded differently to PEGinduced water stress in the medium. Seedlings that emerge fast have better chance to grow better by increasing their length and accumulate more dry matter than those germinate later. Our results showed that RSR was improved with the increase of PEG levels (Table 2) which suggesting that the fraction of dry matter allocated to shoots was lessened compared to the roots. Previous studies showed that the shoot of the wheat seedlings was more affected by the drought stress of the medium than other growth aspects (Boutraa et al., 2010). Furthermore, the difference in shoot length, root length and RSR in response to increasing osmotic potential (Table 2) confirmed variation in seedling utilization of the mechanisms including physiological, morphological, and molecular levels. 'Ahmar' variety had the highest plant height and was notably different to other two varieties. Generally, the highest seedling length is associated with higher GRI and less time of germination. Previous reports showed that severe water deficit resulted in considerably lower growth vigour of wheat seedlings (Shahi et al., 2015). Our results showed clearly that 'Ahmar' variety is more tolerant to drought stress during the seedling establishment stage. 'Zaydia' was found to be vulnerable to drought stress. The higher shoot growth of 'Ahmar' variety may be associated to the intrinsic features of the variety and size of seeds. The mass of one thousand seeds of 'Ahmar' is $37.06 \mathrm{~g}$, while the weight of a thousand seeds of the 'Shahbi' variety is $35.48 \mathrm{~g}$ and 'Zaydia' is $33.25 \mathrm{~g}$. Large sized seeds have a larger amount of reserves mainly carbohydrates to be translocated to the shoot growth when compared to the small-sized seeds (Shahi et al., 2015). Therefore, the use of high-quality seeds of drought tolerant varieties is essential for a successful crop production and food security particularly during the increasing uncertainty due to climate change.

\section{Conclusions}

It can conclude that the variance between cultivars to tolerate drought stress belonged to their intrinsic characteristics. 'Ahmar' variety can tolerate better a rigorous water stress conditions during the seedling establishment stage compared to the 'Shahbi' and 'Zaydia'. However, regardless of the variety, seed priming improved seed germination performance and seed reserve mobilisation and later increased early seedling growth and antioxidant defence system of all sorghum varieties therefore resulting in increased stress tolerance. Furthermore, seed priming was found to enhance the $\alpha$-amylase and total proteases activities in all sorghum varieties. The largest increase of these hydrolysing enzymes was shown in the 'Ahmar' variety. Osmotic priming appears to have boosted antioxidant defense systems resulting in increased stress tolerance. Therefore, the practice of seed priming should be encouraged in drought-prone locations where irrigations is not available.

\section{Acknowledgements}

The authors thank the Deanship of Scientific Research, Jazan University, for financially supporting this research project (grant number JUP8//000343).

\section{Conflict of Interests}

The authors declare that there are no conflicts of interest related to this article. 


\section{References}

Aebi H (1984). Catalase in vitro. Methods in Enzymology 105:121-126.

Ahmad S, Ahmad R, Ashraf MY, Ashraf M, Waraich EA (2009). Sunflower (Helianthus annuus L.) response to drought stress at germination and seedling growth stages. Pakistan Journal of Botany 41(2):647-654.

Amooaghaie R (2013). The effect of hydro and osmopriming on alfalfa seed germination and antioxidant defenses under salt stress. African Journal of Biotechnology 10(33):6269-6275.

Ansari O, Choghazardi HR, SharifZadeh F, Nazarli H (2012). Seed reserve utilization and seedling growth of treated seeds of mountain ray (Secale montanum) as affected by drought stress. Cercetări Agronomice în Moldova 45(2):43-48.

Bhatt RM, Srinivasa-Rao NK (1987). Seed germination and seedling growth responses of tomato cultivars to imposed water stress. Journal of Horticultural Science 62(2):221-225.

Bishnoi NR, Dua A, Gupta VK, Shawhney SK (1993). Effect of chromium on seed germination, seedling growth and yield of peas. Agriculture, Ecosystems and Environment 47(1):47-57.

Bouslama M, Schapaugh WT (1984). Stress tolerance in soybean. Part 1: Evaluation of three screening techniques for heat and drought tolerance. Crop Science 24(5):933-937.

Boutraa T, Akhkha A, Al-Shoaibi AA, Alhejeli AM (2010). Effect of water stress on growth and water use efficiency (WUE) of some wheat cultivars (Triticum durum) grown in Saudi Arabia. Journal of Taibah University for Science 3(1):39-48.

Bove J, Jullien M, Grappin P (2001). Functional genomics in the study of seed germination. Genome Biology 3:1002.11002.5.

Bradford KJ (1986). Manipulation of seed water relations via osmotic priming to improve germination under stress conditions. Horticultural Science 21:1105-1112.

Bray CM (1995). Biochemical processes during the osmopriming of seeds. In: Y Kigel, G Galili (Eds.). Seed Development and Germination. Marcel Dekker, pp 767-789, New York.

Chen K, Arora R (2011). Dynamics of the antioxidant system during seed osmopriming, post-priming germination, and seedling establishment in spinach (Spinacia oleracea). Plant Science 180(2):212-220.

Cruz de Carvalho MH (2008). Drought stress and reactive oxygen species. Plant Signal Behaviour 3(3):156-165.

De R, Kar P (1995). Seed germination and seedling growth of mung bean (Vigna radiata) under water stress induced by PEG-6000. Seed Science Technology 23:301-308.

Ejeta G, Knoll JE (2007). Marker-assisted selection in sorghum. In: Varshney RK and Tuberosa R (Eds.). Genomicassisted crop improvement genomics applications in crops. Netherlands: Springer Netherlands pp 187-205.

Farooq M, Basra SM, Wahid A (2006). Priming of field-sown rice seed enhances germination, seedling established, allometry, and yield. Plant Growth Regulation 49(2-3):285-294.

Finch-Savage WE, Bassel G (2016). Seed vigour and crop establishment: extending performance beyond adaptation. Journal of Experimental Botany 67(3):567-591.

Foyer CH, Noctor G (2005). Oxidant and antioxidant signalling in plants: a re-evaluation of the concept of oxidative stress in a physiological context. Plant, Cell and Environment 28(8):1056-1071.

Ghassemi-Golezani K, Aliloo AA, Valizadeh M, Moghaddam M (2008). Effects of different priming techniques on seed invigoration and seedling establishment of lentil (Lens culinaris Medik.). The Journal of Food, Agriculture and Environment 6(2):222.

Ghoulam C, Foursy A, Fares K (2002). Effects of salt stress on growth, inorganic ions and proline accumulation in relation to osmotic adjustment in five sugar beet cultivars. Environmental and Experimental Botany 47(1):39-50.

Hamidi H, Safarnejad A (2010). Effect of drought stress on alfalfa cultivars (Medicago sativa L.) in germination stage. American-Eurasian Journal of Agricultural \& Environmental Sciences 8:705-709.

Hasanuzzaman M, Nahar K, Alam MM, Roychowdhury R, Fujita M (2013). Physiological, biochemical, and molecular mechanisms of heat stress tolerance in plants. International Journal of Molecular Science 14(5):9643-9684.

Hodges DM, DeLong JM, Forney CF, Prange RK (1999). Improving the thiobar-bituric acid-reacting substances assay for estimating lipid peroxidation in plant tissues containing anthocyanin and other interfering compounds. Planta 207(4):604-611.

Hur S (1991). Effect of osmoconditioning on the productivity of Italian ryegrass and sorghum under suboptimal conditions. Korean Journal of Animal Science (Korea Republic). 
Jisha K, Vijayakumari K, Puthur JT (2013). Seed priming for abiotic stress tolerance: an overview. Acta Physiologia Plantarium 35(5):1381-96.

Jones R, Varner J (1967). The bioassay of gibberellins. Planta 72(2):155-161.

Khadraji A, Mouradi M, Houasli C, Qaddoury A, Ghoulam C (2017). Growth and antioxidant responses during early growth of winter and spring chickpea (Cicer arietinum) under water deficit as affected by osmopriming. Seed Science and Technology 45(1):198-211.

Khan K, Gul Ullah Z, Afsar A, Uddin I, Ullah H (2014). Effect of different osmopriming sources and levels on germination and root length of sorghum. Weekly Science Research Journal 1:1-5.

Khodarahmpour Z (2011). Effect of drought stress induced by polyethylene glycol (PEG) on germination indices in corn (Zea mays L.) hybrids. African Journal of Biotechnology 10(79):18222-18227.

Kibinza S, Bazin J, Bailly C, Farrant JM, Corbineau F, El-Maarouf Bouteau H (2011). Catalase is a key enzyme in seed recovery from ageing during priming. Plant Science 181(13):309-315.

Labouriau LG (1983). A germinação de sementes. Washington: Organização dos Estados Americanos, pp 174.

Li C, Cao X, Gu Z, Wen H (2011). A preliminary study of the protease activities in germinating brown rice (Oryza sativa L.). Journal of the Science of Food and Agriculture 91(5):915-920.

Machado-Neto NB, Custódio CC, Castilho C, Costa PR, Doná FL (2006). Deficiência hídrica induzida por diferentes agentes osmóticos na germinação e vigor de sementes de feijão. Revista Brasilica Sementes 28(1):142-148.

Maguire JD (1962). Speed of germination-aid in selection and evaluation for seedling emergence and vigour. Crop Science 2(2):176-177.

Maheshwari R, Dubey RS (2008). Inhibition of ribonuclease and protease activities in germinating rice seeds exposed to nickel. Acta Physiologia Plantarium 30(6):863.

Marambe B, Ando T, Kouno K (1992). Alpha-amylase and protease activities and water relations in germinating sorghum (Sorghum bicolor Moench) seeds as affected by animal-waste composts. Soil Science and Plant Nutrition 38(1):123-131.

McDonald MB (1999). Seed deterioration. Physiology, repair and assessment. Seed Science and Technology 27(1):177237.

Meneses CHSG, Bruno RLA, Fernandes PD, Pereira WE, Lima LHGM, Lima MMA, Vidal MS (2011). Germination of cotton cultivar seeds under water stress induced by polyethyleneglycol-6000. Scientia Agricola 68(2):131-138.

Michel BE, Kaufmann MR (1973). The osmotic potential of polyethylene glycol 6000. Plant Physiology 51:914-916.

Nascimento WM, West SH (1998). Priming and seed orientation affect emergence and seed coat adherence and seedling development of muskmelon transplants. Horticultural Science 33(5):847-848.

Oliveira AB, Gomes-Filho E (2009). Germinação e vigor de sementes de sorgo forrageiro sob estresse hídrico e salino. Revista Brasilica Sementes 31(3):48-56.

Patade VY, Maya K, Zakwan A (2011). Seed priming mediated germination improvement and tolerance to subsequent exposure to cold and salt stress in capsicum. Research Journal of Seed Science 4(3):125-136.

Rahimi A (2013). Seed priming improves the germination performance of cumin (Cuminum syminum L.) under temperature and water stress. Industrial Crops and Products 42:454-460.

Rouhi HR, Aboutalebian MA, SharifZadeh F (2011). Effects of hydro and osmopriming on drought stress tolerance during germination in four grass species. International Journal of AgriScience 1(2):107-114.

Rouhi HR, Aboutalebian MA, Moosavi SA, Karimi FA, Karimi F, Saman M, Samadi M (2012). Change in several antioxidant enzymes activity of Berseem clover (Trifolium alexandrinum L.) by priming. International Journal of AgriScience 2(3):237- 243.

Sadeghi H, Khazaei F, Yari L, Sheidaei S (2011). Effect of seed osmopriming on seed germination behaviour and vigour of soybean (Glycine max L.). ARPN Journal of Agricultural and Biological Science 6(1):39-43.

SAS Institute Inc (2004). SAS Users Guide, version 9.1. SAS Institute, Inc., Cary, NC.

Shahi C, Vibhuti KB, Bargali SS (2015). How seed size and water stress affect the seed germination and seedling growth in wheat varieties? Current Agriculture Research Journal 3(1):60-68.

Sharma P, Jha AB, Dubey RS Pessarakli M (2012). Reactive oxygen species, oxidative damage, and antioxidative defense mechanism in plants under stressful conditions. Journal of Botany 217037. http://dx.doi.org/10.1155/2012/217037.

Shihab MO, Hamza JH (2019). Seed priming of sorghum cultivars to tolerate salt stress. IOP Conference Series: Earth and Environmental Science 388(1):012044. 
Sikder S, Hasan MA, Hossain MS (2009). Germination characteristics and mobilization of seed reserves in maize varieties as influenced by temperature regimes. Journal of Agriculture and Rural Development 51-58.

Soltani A, Gholipoor M, Zeinali E (2006). Seed reserve utilization and seedling growth of wheat as affected by drought and salinity. Environmental and Experimental Botany 55(1-2):195-200.

Subramani T, Manjunath K, Chandrashekharaiah K, Ramachandra Swamy N, Siddalinga Murthy K (2011). Variations in the esterase activity during the germination period of Jatropha curcas seeds. Journal of Phytology 3(11):1-3.

Sun YY, Sun YJ, Wang MT, Li XY, Guo X, Hu R, Ma J (2010). Effects of seed priming on germination and seedling growth under water stress in rice. Acta Agronomica Sinnica 36(11):1931-1940.

Taiz L, Zeiger E, Moller IM, Murphy A (2017). Fisiologia e desenvolvimento vegetal. Porto Alegre: Artmed, 6th ed., pp 888.

Teshome W, Tana T, Dechassa N, Singh TN (2018). Effect of seed priming on germination and seedling growth of grain sorghum (Sorghum bicolor L. Moench) varieties. East African Journal of Sciences 12(1):51-60.

Texeira LR, Braccini AL, Sperandio D, Scapim CA, Schuster I, Vigan, J, Jaremtchuk CC (2008). Avaliação de cultivares de soja quanto à tolerância ao estresse hídrico. Revista Ceres 55:194-202.

Tounekti T, Abreu Khemira H, Munné-Bosch S (2012). Canopy position determines the photoprotective demand and antioxidant protection of leaves in salt stressed Salvia officinalis L. plants. Environmental and Experimental Botany 78:146-156.

Tounekti T, Mahdhi M, Al-Turki TA, Khemira H (2018). Water relations and photo-protection mechanisms during drought stress in four coffee (Coffea arabica) cultivars from south-western Saudi Arabia. South African Journal of Botany 117:17-25.

Tsago Y, Andargie M, Takele A (2014). In vitro selection of sorghum (Sorghum bicolor (L.) Moench) for polyethylene glycol (PEG) induced drought stress. Plant Science Today 1(2):62-68.

Wang WB, Kim YH, Lee HS, Kim KY, Deng XP, Kwak SS (2009). Analysis of antioxidant enzyme activity during germination of alfalfa under salt and drought stresses. Plant Physiology and Biochemistry 47(7):570-577.

Yacoubi R, Job C, Belghazi M, Job D (2013). Proteomic analysis of the enhancement of seed vigour in osmoprimed alfalfa seeds germinated under salinity stress. Seed Science Research 23(2):99-110.

Zhang F, Yu J, Johnston CR, Wang Y, Zhu K, Lu F, ... Zou J (2015). Seed priming with polyethylene glycol induces physiological changes in sorghum (Sorghum bicolor L. Moench) seedlings under suboptimal soil moisture environments. PLoS ONE 10(10):e0140620. https://doi.org/10.1371/journal.pone.0140620

Zhang S, Hu J, Zhang Y, Xie XJ, Allen K (2007). Seed priming with brassinolide improves lucerne (Medicago sativa L.) seed germination and seedling growth in relation to physiological changes under salinity stress. Australian Journal of Agricultural Research 58(8):811-815.

Zrig A, Ferreira JFS, Hamouda F, Tounekti T, Selim S, Al Jaouni S, ... Abdelgawad H (2019). The impact of foliar fertilizers on growth and biochemical responses of Thymus vulgaris to salinity stress. Arid Land Research and Management 33(3):297-320.
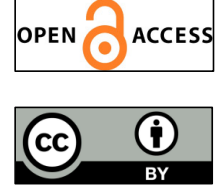

The journal offers free, immediate, and unrestricted access to peer-reviewed research and scholarly work. Users are allowed to read, download, copy, distribute, print, search, or link to the full texts of the articles, or use them for any other lawful purpose, without asking prior permission from the publisher or the author.

License - Articles published in Notulae Botanicae Horti Agrobotanici Cluj-Napoca are Open-Access, distributed under the terms and conditions of the Creative Commons Attribution (CC BY 4.0) License. (C) Articles by the authors; UASVM, Cluj-Napoca, Romania. The journal allows the author(s) to hold the copyright/to retain publishing rights without restriction. 